\title{
COMPARATIVE SUSTAINABILITY ASSESSMENT USING THREE RATING SYSTEMS IN THE MYANMAR CONTEXT
}

\author{
T. SHWE ${ }^{1}, \mathrm{~K} . \mathrm{IKI}^{1} \&$ R. HOMMA ${ }^{2}$ \\ ${ }^{1}$ Department of Architecture and Environment Planning, Graduate School of Science and Technology, \\ Kumamoto University, Japan. \\ ${ }^{2}$ Architectural History and Urban Planning, Faculty of Advanced Science and Technology, \\ Kumamoto University, Japan.
}

\begin{abstract}
To address the gap of sustainable development in developing countries, this study conducted a sustainability assessment of multiple neighbourhood developments in Myanmar using well-known international rating systems/tools established in developed countries. The study examined three cases, each a neighbourhood development in three significant cities, using the three rating systems. First, the study content analysed the three tools to determine the effectiveness of the rating systems. Following this, evaluation performances reflected the degree of compliance of the cases with each system through different results of specific developments. The shortcomings of the selected tools and weaknesses of the case studies determined that there is no perfect tool from developed countries to demonstrate the sustainability performance of the cases in developing countries. This research successfully interpreted the strengths and weaknesses of the Myanmar case studies to strengthen sustainability in the future.

Keywords: BREEAM communities, CASBEE-UD, developing country, LEED-ND, Mandalay, Myanmar, neighbourhood development, Pathein, sustainability assessment, Yangon.
\end{abstract}

\section{INTRODUCTION}

Recognising the critical role of neighbourhoods as the frontline in sustainable cities, many initiatives have been undertaken to create sustainable neighbourhood developments, and several tools have been developed to assess and rate the sustainability performance of these developments. In developing countries, even though several reports highlight the failures of sustainability [1], no research has been conducted on multiple developments and their performance using specific assessment and rating systems, especially in Myanmar. To initiate this practice in developing countries, this research measures, assesses, reflects and compares the sustainability performance of neighbourhood developments in Myanmar. The specific aims and objectives are (1) to examine the effectiveness of selected sustainability assessment and rating systems/tools, (2) to evaluate and assess selected case studies using these tools, and (3) to compare their assessment results and performance to highlight common weaknesses and strengths in their sustainability pathways.

\section{METHODS AND MATERIALS}

By adopting a comparative case studies approach, this study employed both quantitative and qualitative techniques. To assess the performance of each development through specific assessment systems, the latest version of the neighbourhood sustainable assessment (NSA) tool was applied in terms of three systems, namely BREEAM Communities [2], CASBEE-UD [3] and LEED-ND [4], which were selected based on their worldwide recognition. To determine the effectiveness of these tools, the indicators, which are the building components of every assessment tool, were investigated through content analysis. Sharifi [5] stated that to fulfil the role of facilitator, the indicators must be integrated (cover multiple issues and consider the linkages between them) [6], forward looking (intergenerational equity), distributional (intra-generational equity), developed with input from multiple stakeholders (procedural equity) [6, 7], and context-specific. Here, the content 
analysis examined 148 indicators used in the three tools in terms of these five core characteristics to determine compliance.

Following this, the selected three case studies were practically assessed using the selected tools, and a minimum of 444 calculations was conducted. This means that for the three case studies assessed according to the three tools, the results of nine assessments reflect different scores. For the results to be comparable, the scores of all case studies were converted into mean achievements for three sustainability dimensions and nine sustainability categories. According to different organising themes, the descriptions of the indicators, and their scoring methods, the respective mean proportions were calculated for the three tools. Finally, the mean proportions were compared to highlight common weaknesses and strengths of Myanmar neighbourhood developments in their sustainable pathways to the future.

\section{REVIEW AND CONTENT ANALYSIS OF SELECTED TOOLS}

To synthesise the characteristics of the three tools, a set of items was investigated as shown in Table 1, which presents the key characteristics of the three selected tools. Table 1 also provides basic information on the systems.

When Shwe [8] investigated the weight and proportion of indicators, it was found that these three tools mainly focused on environmental issues having unbalanced in terms of the three sustainability dimensions, as shown in Fig. 1a. Across the nine sustainability categories,

Table 1: Key characteristics of the three selected tools.

\begin{tabular}{llll}
\hline Items & \multicolumn{2}{l}{ BREEAM- Communities CASBEE- UD } & LEED- ND \\
\hline Used Version & 2012 Updated in 2013 & 2014 & 2009 Updated in 2014 \\
Developer & BRE Global & $\begin{array}{l}\text { Sustainable Building } \\
\text { Consortium }\end{array}$ & $\begin{array}{l}\text { U.S. Green Building } \\
\text { Council }\end{array}$ \\
Country & UK & Japan & USA \\
Themes & 6 (Including Innovation) & 4 (Including Load) & 4 (Including Innovation) \\
Indicators & 41 & 52 & 55 \\
Rating & 6 ranks & 5 ranks & 4 ranks \\
\hline
\end{tabular}

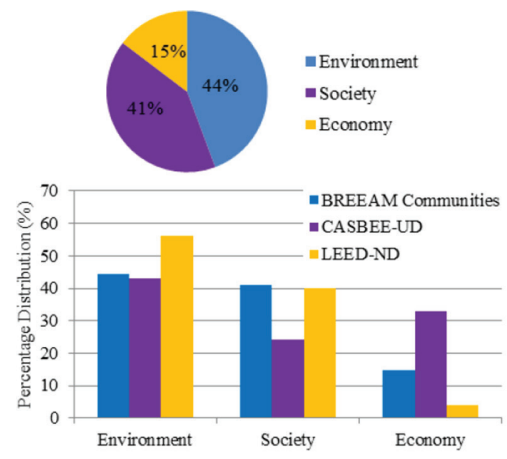

(a)

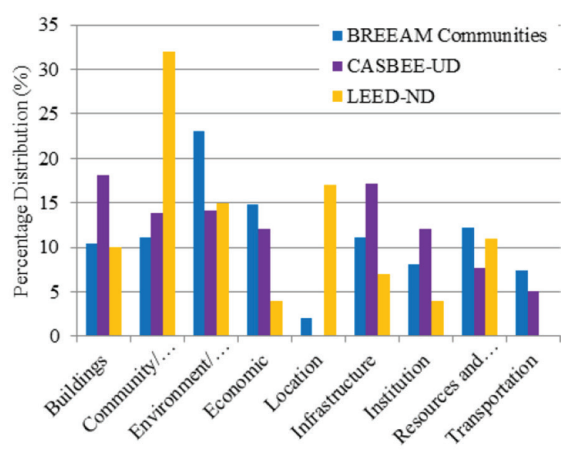

(b)

Figure 1: (a) Mean proportion and distribution of weighted indicators across three sustainable dimensions and (b) distribution of weighted indicators across nine sustainability categories [8]. 
Shwe [8] also emphasised the weaknesses of the three tools in terms of indicator distributions. Although each tool should consider enough distribution in each category, they tend to focus on different targets. For example, CASBEE-UD does not account for location indicator and LEED-ND does not consider transportation indicator, as shown in Fig. 1b.

Before assessing the non-native case studies, it is important to determine the effectiveness of the selected sustainability assessment and rating tools. Adopting a qualitative approach, the results of the content analysis are shown in Table 2, which describes the compliance of the three selected tools with the five core characteristics mentioned earlier. The composition of the constituents of the tools, their qualities, and interrelations were thoroughly examined.

Table 2: Compliances of five core characteristics of the three selected tools.

\begin{tabular}{|c|c|c|c|}
\hline $\begin{array}{l}\text { Core Charac- } \\
\text { teristics }\end{array}$ & $\begin{array}{l}\text { BREEAM- } \\
\text { Communities }\end{array}$ & CASBEE- UD & LEED- ND \\
\hline \multirow{2}{*}{$\begin{array}{l}\text { Integrating } \\
\text { (Balance } \\
\text { Coverage) }\end{array}$} & FAIR & GOOD & POOR \\
\hline & $\begin{array}{l}\text { Lowest in economic } \\
\text { indicators, but the } \\
\text { other two have simi- } \\
\text { lar ratios }\end{array}$ & $\begin{array}{l}\text { Strong in environmental } \\
\text { indicators followed by } \\
\text { economic and society } \\
\text { respectively, but the differ- } \\
\text { ence is quite low }\end{array}$ & $\begin{array}{l}\text { Very strong in environ- } \\
\text { ment and very weak in } \\
\text { economic indicators }\end{array}$ \\
\hline \multirow{2}{*}{$\begin{array}{l}\text { Integrating } \\
\text { (Distribution) }\end{array}$} & GOOD & POOR & POOR \\
\hline & $\begin{array}{l}\text { Distributed in all nine } \\
\text { categories }\end{array}$ & $\begin{array}{l}\text { Not addressed in location } \\
\text { indicators }\end{array}$ & $\begin{array}{l}\text { Not addressed in transpor- } \\
\text { tation indicators }\end{array}$ \\
\hline \multirow{2}{*}{$\begin{array}{l}\text { Forward } \\
\text { Looking }\end{array}$} & FAIR & FAIR & FAIR \\
\hline & $\begin{array}{l}\text { Identified normal } \\
\text { conditions at present } \\
\text { and forward looking } \\
\text { for the future }\end{array}$ & $\begin{array}{l}\text { Identified normal con- } \\
\text { ditions at present and } \\
\text { forward looking for the } \\
\text { future }\end{array}$ & $\begin{array}{l}\text { Identified normal con- } \\
\text { ditions at present and } \\
\text { forward looking for the } \\
\text { future }\end{array}$ \\
\hline \multirow{2}{*}{$\begin{array}{l}\text { Intra-genera- } \\
\text { tional Equity }\end{array}$} & GOOD & FAIR & GOOD \\
\hline & $\begin{array}{l}\text { Concrete measures } \\
\text { regarding equal ac- } \\
\text { cessibility }\end{array}$ & $\begin{array}{l}\text { Concrete measures regard- } \\
\text { ing equal accessibility but } \\
\text { not for different income }\end{array}$ & $\begin{array}{l}\text { Concrete measures } \\
\text { regarding equal acces- } \\
\text { sibility }\end{array}$ \\
\hline \multirow{2}{*}{$\begin{array}{l}\text { Procedural } \\
\text { Equity }\end{array}$} & GOOD & FAIR & FAIR \\
\hline & $\begin{array}{l}\text { High priority for } \\
\text { cooperation including } \\
\text { community }\end{array}$ & $\begin{array}{l}\text { Cooperation between } \\
\text { industry, government and } \\
\text { academia but low in public } \\
\text { participation }\end{array}$ & $\begin{array}{l}\text { Cooperation accounted } \\
\text { for, but low in public } \\
\text { participation }\end{array}$ \\
\hline \multirow{2}{*}{$\begin{array}{l}\text { Context- } \\
\text { specificity }\end{array}$} & FAIR & POOR & FAIR \\
\hline & $\begin{array}{l}\text { Additional credit } \\
\text { could be applied as } \\
\text { innovation }\end{array}$ & $\begin{array}{l}\text { Strongly bounded with } \\
\text { system's region of origin } \\
\text { and no consideration for } \\
\text { local-specificity require- } \\
\text { ments }\end{array}$ & $\begin{array}{l}\text { Different indicators for } \\
\text { various types of develop- } \\
\text { ment } \\
\text { Additional credits could } \\
\text { be applied as innovation } \\
\text { and regional priority }\end{array}$ \\
\hline
\end{tabular}


Regarding previous studies by Shwe [8], BREEAM Communities integrates the three sustainable dimensions and considers all nine categories. CASBEE-UD tries to balance the three dimensions, but lacks even indicator distribution. In the case of LEED-ND, the differences between the distributions of indicators are high, making coverage unbalanced. For intragenerational equity, the tool should be assessed in terms of considerations of all citizens such as equal accessibility, affordable housing and equal distribution. Regarding this issue, BREEAM Communities and LEED-ND perform well, while CASBEE-UD omits assessments of income diversity such as affordable housing. Regarding procedural equity, BREEAM Communities includes the participation of various stakeholders and assesses public participation in each step of the master planning process. Finally, assessment tools should be flexible enough to suit the local context in which development is implemented, especially for issues such as different climates, different types of development, and various phases of development. BREEAM Communities and LEED-ND assign additional credits to innovation. Although LEED-ND also assigns additional credits to regional priorities, the quality is not high, because the indicators assessed for climate adaptation are bound to national criteria. Obviously, the benchmarks of the CASBEE-UD calculations of environmental load are strongly bounded with the system's region of origin. Finally, the overall results of the content analysis indicated that BREEAM Communities is the only tool to address all issues, despite having some weaknesses.

\section{OVERVIEW OF SELECTED CASE STUDIES}

Myanmar, officially known as the Republic of the Union of Myanmar, is a developing country situated in southeast Asia. Currently, it seems to have the most potential for rapid growth and large-scale development aligned to democratic reforms. Although the first-known citystates emerged in central Myanmar in the 2nd century BC, most city patterns were shaped by British colonisation in the 18th century. In this study, the three significant neighbourhood developments were selected from Yangon, Mandalay and Pathein which city patterns were also based on colonialized port cities.

Yangon, the biggest city in Myanmar, is the former capital of the country and now capital of the Yangon region. The city plays a leading role as the economic and knowledge hub of Myanmar. It is growing daily and becoming one of Asia's megacities. Mandalay is the second largest city, the last capital of the Myanmar kingdom, and the current capital of the Mandalay region. The city is currently the cultural hub of Myanmar and the economic centre for upper Myanmar. Pathein city is the capital of the Ayeyawady region and one of Myanmar's international port cities. In addition, the region is well-known as the granary of Myanmar.

One significant case study was selected from each city based on the dominants position, leading role of sustainability in their region, current on-going status, and similar theme of mixed use development located in respective city' urban area. Selected projects were the Golden City (GC) [9] project in Yangon, Mingalar Mandalay (MM) [10] project in Mandalay, and Mya Kyun Thar (MKT) [11] project in Pathein. These case studies have similar facilities, namely luxury condominiums, luxury villas, apartments, offices, hotels, shopping centres, shop houses, restaurants, banks, recreation centres such as gyms and pools. Because of the variety in size, as shown in Table 3, only MKT can attempt the inclusion of a school, monastery and area for future extensions. Each development has endeavoured to set up large car parking areas and green spaces. 
Table 3: Significant factors of the three case studies.

\begin{tabular}{lllll}
\hline Sr. No. & Descriptions & $\begin{array}{l}\text { GC } \\
\text { (Yangon) }\end{array}$ & $\begin{array}{l}\text { MM } \\
\text { (Mandalay) }\end{array}$ & $\begin{array}{l}\text { MKT } \\
\text { (Pathein) }\end{array}$ \\
\hline 1 & Site Area (Acres) & 8.37 & 47.00 & 145.05 \\
2 & Coverage Ratio (\%) & 73.89 & 52.26 & 28.44 \\
3 & Green Area Ratio (\%) & 26.11 & 20.47 & 13.00 \\
4 & Permeable surface Ratio (\%) & $<5$ & 20.47 & 25 \\
5 & Floor Area Ratio (\%) & $1,060.43$ & 176.05 & 125.76 \\
6 & Density Ratio (Dwelling Unit/Acres) & 835.49 & 14.71 & 6.20 \\
\hline
\end{tabular}

Aiming one of Myanmar National Landmark, GC is developed by the Golden Land real estate development Co. Ltd., which is a Singapore-Myanmar joint venture company. Valuing heritage assets, Yangon is sensitive to its vertical growth. Currently, GC development with very high density is standing as the tallest skyscraper in Yangon as well in Myanmar. The development had been paid attention to preserve the skyline as well as to conserve the existing building within the development. Another remarkable feature of the GC is that it includes the first installation in Myanmar of auto-operated car parking system in the basement and ground floor with an overhead shifted landscape layer. In honour of its outstanding contribution to improving human habitats in Asia, the Asian Habitat Society awarded GC the Green Asia Habitat Award.

The New Star Light Construction Co. Ltd. is developing MM, which has become the benchmark for Mandalay's modernisation. Adapting to the hot and dry regional climate, the MM pattern is based on the local complex layout, which includes multiple courtyards. Only half the site is occupied by buildings, which are linked to green areas with permeable surfaces.

The Delta Industrial Group is developing Mya Kyun Thar for the purpose of building the first large-scale housing complex in Pathein and providing their group industrial development. Among these three case studies, this mixed-use development is the most diverse, also comprising education and religious facilities. As a local city, the project density is very low, and only one third of the site area is occupied by buildings. Furthermore, the vertical growth of the development is very low, and most of the area is connected to green permeable surface areas. A large volume of man-made water spaces was created as retention ponds. Its vacant open space for future extension is also a remarkable feature.

To summarise, while all the case studies have in common residential, commercial, and institutional facilities, they have different characteristics in terms of vertical or horizontal growth and development design, as shown in Fig. 2. Strategically located in the international city Yangon, the high-density GC project was developed using advanced technologies and creative design ideas to reflect its international style. Located in the cultural city of Mandalay, MM reflects traditional concepts only in its layout, although most of the development features are localised contemporary design. Of these two cities, Pathein is a local city paralleling the third level of the nation, and as such, MKT is the lowest density development that reflects the use of localised technology. 

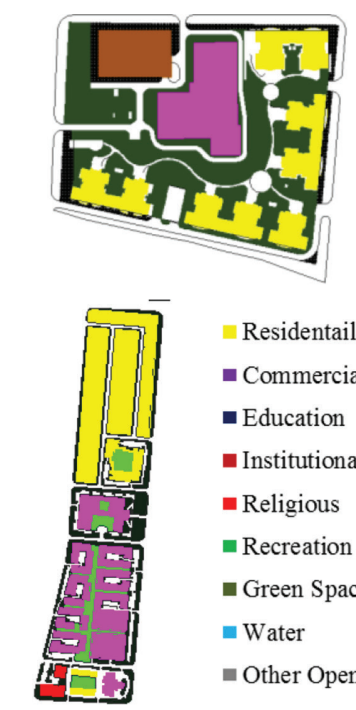

Residentail

- Commercial

- Education

- Institutional

- Religious

- Recreation

- Green Space

w Water

- Other Open Space
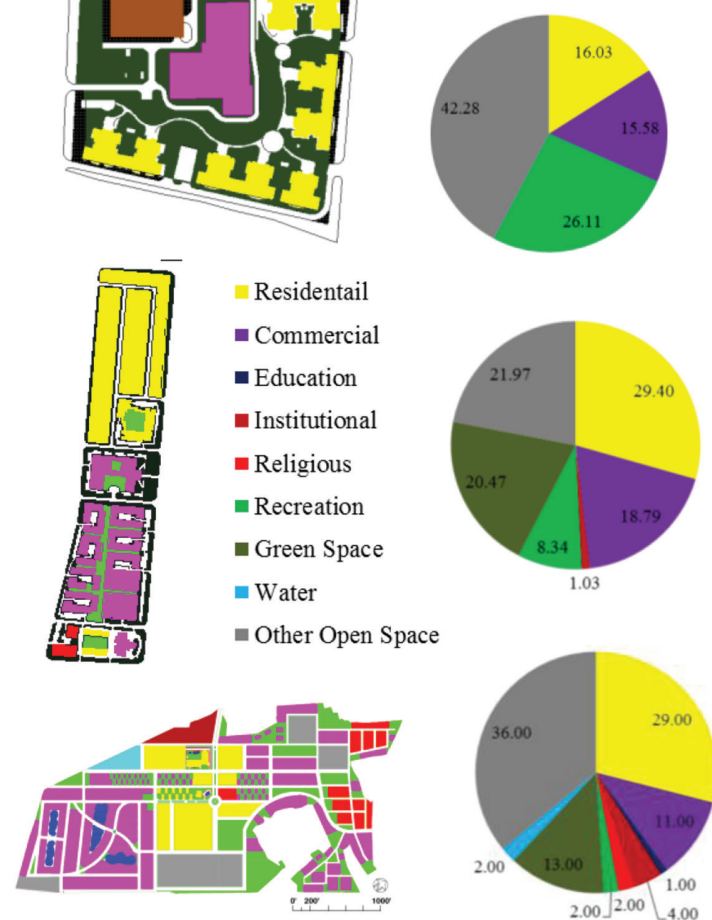

(a)

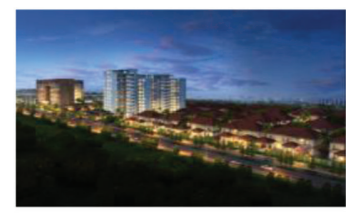

(b)
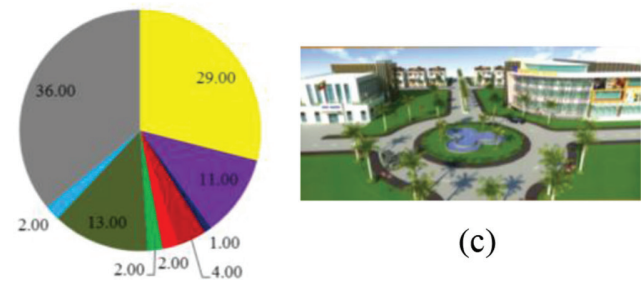

(c)

Figure 2: Land utilization, ratio and overall perspective; (a) Golden City, (b) Mingalar Mandalay and (c) Mya Kyun Thar.

\section{ASSESSMENT RESULTS}

Consequent to the idiosyncrasies of the selected cases and variations in the criteria of various tools, the degree of compliance with each tool is graphically presented in Table 4. The radar charts represent the various themes of each tool and the achieved scores of each case study. The number of black stars for the results of each case represents the star-ratings assigned by each tool.

For BREEAM Communities, all case studies scored highly for social and economic wellbeing, but very low for other themes though the results for all cases are similar and quite low. The CASBEE-UD results indicate balanced performances for the three environment quality themes for all three cases. While the results are similar, the rank certifications differ. Although LEED-ND indicates different patterns, all cases do not earn high sustainability ranks. Overall, the different tools provided different ratings for the same developments. For example, LEED-ND ignored the sustainability contributions of all cases, while CASBEE-UD assigned a high rating, which is the opposite outcome.

For more correspondence, all scores were converted into 100 marks so that the compared ratio of each case was evident, as shown in Figure 3. The results of all three tools indicate that the cases scored within 20-40 intervals. Therefore, the achievements do not differ much among cases, because the ranking scores divided by each tool differ. Of the 100 marks, BREEAM Communities divides 6 intervals. Here, GC and MM 'Pass', while MKT is 'Unclassified'. The CASBEE-UD classified three ranks in the first three intervals out of ten; thus, the three case studies scored different ratings, namely very good, fairly poor, and good. 
Table 4: Degree of assessment results compliance by the three tools.

$\begin{array}{lll}\text { Achievements of GC } & \text { Achievements of MM } & \text { Achievements of MKT }\end{array}$

By BREEAM Communities

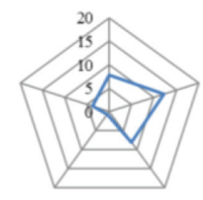

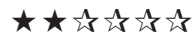

By CASBEE-UD

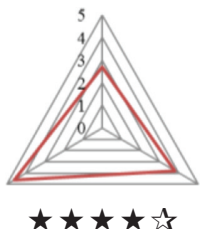

By LEED-ND

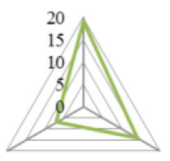

太认必拧

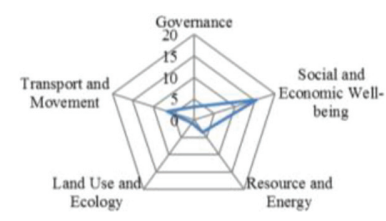

$\star \star え え એ 之$

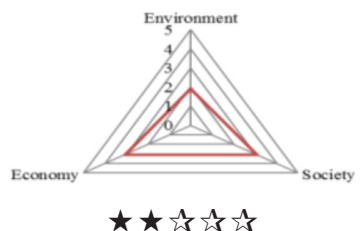

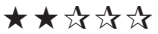

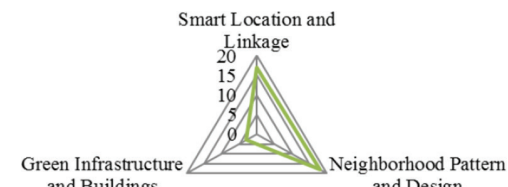

and Buildings

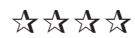

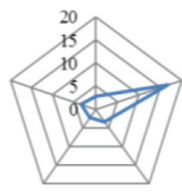

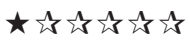

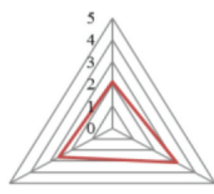

$\star \star \star え え$

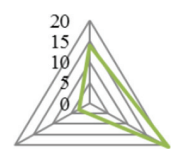

એえだ

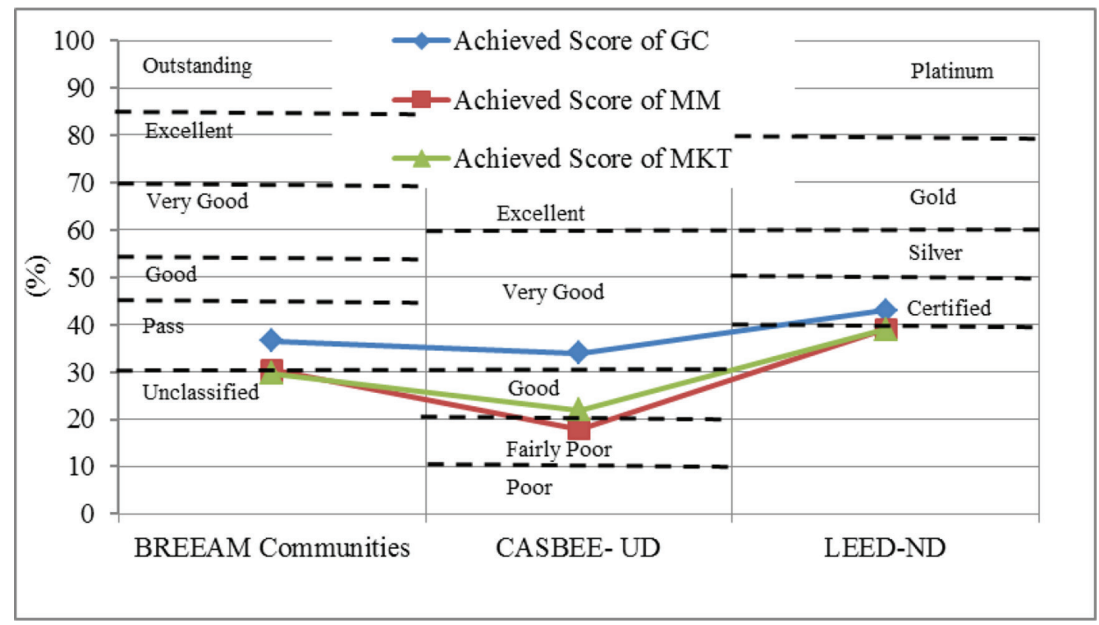

Figure 3: Comparison of assessment results by means of achieved scores. 
Since the LEED-ND rank score started over the fourth interval, only GC scored the lowest level 'Certified', while the other two case studies did not earn a certification rank.

Although all selected cases are committed to some sustainability practices, they failed to score highly, because the tools have different benchmark compositions for the same purpose. This becomes challenging for neighbourhood developments in developing countries. Challenges in BREEAM Communities were providing evidence of the pre-assessment and analysis results on specific development, consultation with multiple stakeholders in each step, and long-term maintenance and management strategies for a specific indicator. For CASBEE-UD, failures were due to the bound benchmark calculations for environmental load. Even though some developments such as the MKT have affordable housing contributions, this cannot be applied in the CASBEE-UD. Similarly, in LEED-ND, because there are no specific indicators or benchmarks for local content, all cases failed to score for indicators such as climate solar orientation and the heat island effect. Moreover, all cases failed to confirm professional recognitions such as for architects, landscape architects, and ecologists. On the other hand, since BREEAM Communities and LEED-ND are bound with mandatory indicators, all cases failed to earn in some of these indicators. For this reason, they cannot confirm high sustainability performances, especially in the LEED-ND.

\section{DISCUSSION}

These multiple assessment actions demonstrate that the results of the three tools, which were formulated in developed countries, assign different meanings to specific developments in case studies in developing countries. To point out the common weaknesses and strengths of their sustainable pathways, the assessment results and scores were transformed into the mean ratio and compared with those of the three selected tools.

As shown in Figure 4, the selected tools strongly target the environment, then society, followed by the economy. The mean achievements seem similar for the environment and society, followed by economy; therefore, the gap between the mean proportion of the three tools and the achievements of the cases is large for the environment indicators. Across these three sustainability dimensions, the achievements of the three case studies are not that different, although GC ranks first, followed by MM and MKT. Another result shown in Figure 5 indi-

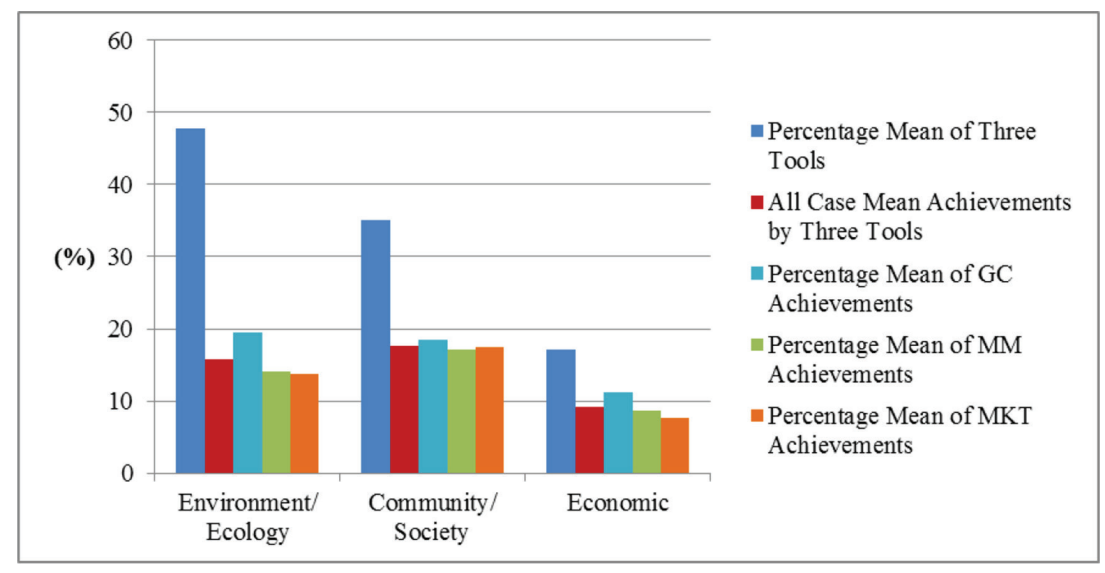

Figure 4: Comparison on mean proportion of three tools and mean achievements of three case studies across three sustainable dimensions. 


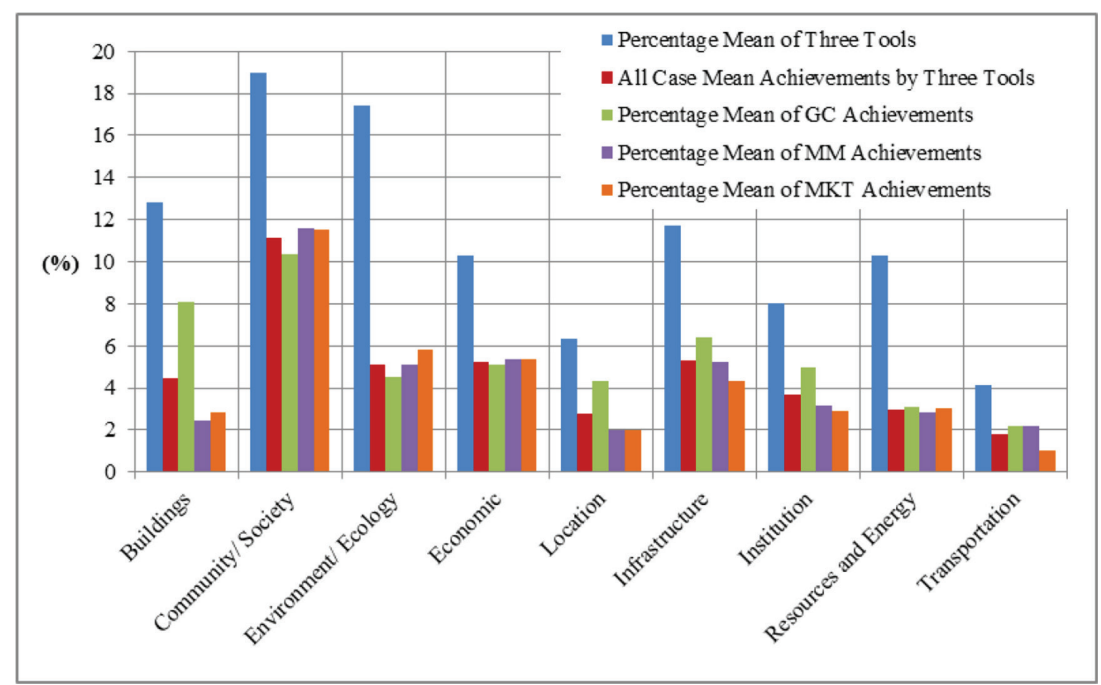

Figure 5: Comparison on mean proportion of three tools and mean achievements of three case studies across nine sustainability categories.

cates that all cases performed well across all nine categories and the gaps between them are only seen large for the building, environment, infrastructure, and resources and energy categories. In these nine categories, the differences between the achievements of the three case studies are evident. Specifically, in the building category, GC scored nearly two-thirds higher than the other developments, because of its green design, which was awarded by a third-party organisation. The remaining two cases did not score as highly.

The results of an in-depth analysis of each of the nine categories are presented in Table 5, which provides the common strengths and weaknesses of the three case studies according to the three tools. The strengths reveal how successful the selected neighbourhood developments have been in terms of implementing sustainability criteria, while the weaknesses expose the way forward for developments in Myanmar to ensure their sustainability into the next generation. For example, to ensure the sustainability of urban areas, the building sector should be incorporated into sustainable attitudes. Most important is providing a fair universal design within the development for all citizens including the elderly and people with disabilities. Since all the cases did not perform well in the environment, infrastructure, and resources and energy categories, a systematic measure should be formulated for conditional multiple assessments, sustainability strategies, and the implementation of community involvement in line with the city's rules and regulations.

Based on the overall experience, the selected rating tools assigned opposite ranks for specific developments, especially the CASBEE-UD and LEED-ND. All case studies faced challenges in confirming their sustainability in the various systems, because these tools have weaknesses in terms of compliance with core characteristics such as integrating and contextspecificity. BREEAM Communities performs well because of its balanced coverage ratio, distribution in all categories, compliance of core characteristics and fair marking intervals for rankings. However, this system is not well suited to case studies in developing countries, because its indicators are bound with multiple criteria that make the challenges to earn high score. For the CASBEE-UD, the five separate benchmark levels for environmental quality make it easy for case studies in developing countries. However, major challenges for this 
Table 5: Common strengths and weaknesses of the three case studies.

\begin{tabular}{|c|c|c|}
\hline Items & Common Strengths & Common Weaknesses \\
\hline Building & $\begin{array}{l}\text { Housing provision for all income } \\
\text { types } \\
\text { Historic building preservation }\end{array}$ & $\begin{array}{l}\text { Excepting GC: } \\
\text { No green wall and roof, no sustainable } \\
\text { and/or green certified building }\end{array}$ \\
\hline $\begin{array}{l}\text { Society/ } \\
\text { Community }\end{array}$ & $\begin{array}{l}\text { Conveniences for daily activities } \\
\text { within walking distance }\end{array}$ & $\begin{array}{l}\text { No provision of universal design for } \\
\text { people with disabilities }\end{array}$ \\
\hline $\begin{array}{l}\text { Environment/ } \\
\text { Ecology }\end{array}$ & $\begin{array}{l}\text { Specific green space ratio } \\
\text { Large volume of permeable sur- } \\
\text { face only in the Pathein case study }\end{array}$ & $\begin{array}{l}\text { Disaster risk assessment and manage- } \\
\text { ment } \\
\text { No strategy for pollution and } \mathrm{CO}_{2} \\
\text { reduction } \\
\text { Long-term strategy of habitat spaces } \\
\text { for species } \\
\text { No treatment system for garbage waste, } \\
\text { sewage, and waste water }\end{array}$ \\
\hline Economic & $\begin{array}{l}\text { Job proximity and employment } \\
\text { within the development }\end{array}$ & $\begin{array}{l}\text { Economic impact survey } \\
\text { Local food production }\end{array}$ \\
\hline Location & Easy access to public transit & - \\
\hline Infrastructure & - & $\begin{array}{l}\text { A few backup systems } \\
\text { Low level of development } \\
\text { No cycling network and facilities }\end{array}$ \\
\hline Institution & $\begin{array}{l}\text { Consultation and design review } \\
\text { within governance and with the } \\
\text { developer }\end{array}$ & $\begin{array}{l}\text { No rules and regulations, guidelines, or } \\
\text { strategy for long-term conservation and } \\
\text { management }\end{array}$ \\
\hline $\begin{array}{l}\text { Resources and } \\
\text { Energy }\end{array}$ & - & $\begin{array}{l}\text { No strategy for the conservation of } \\
\text { natural resources and energy } \\
\text { No strategy for rainwater harvesting } \\
\text { Usage of low-impact materials }\end{array}$ \\
\hline Transportation & - & No assessment for transportation \\
\hline
\end{tabular}

system were found for the environmental load calculation, because it is bound to the context of the system's region of origin. Strength of the LEED-ND was the selection of benchmarks based on different types of developments. However, this system also includes many indicators bound to its region of origin.

Nevertheless, these three tools scored highest for high-density developments and the lowest for low density and high diversity developments. This indicates that developing countries should formulate their own rating system that is more suited to the principles of their level of development, culture, climate, and urban development priorities for sustainable development. Further challenges included weaknesses in the selected case studies. Thus, Myanmar urgently needs to develop related guidelines for urban development, strategies to reduce disaster risk and for the conservation of energy use and natural resources conservation from a long-term perspective to promote sustainability. Localised and citywide strategies should be developed to parallel development at the neighbourhood level. This research revealed the shortcomings of three assessment tools and provided recommendations for future improvements in developing countries. 


\section{CONCLUSION}

This paper conducted a content analysis to determine the effectiveness and compliance of three selected tools. The analysis revealed that there is no perfect tool with which to assess neighbourhood development in developing countries by presenting different and opposite evaluation results for specific developments. This revealed the shortcomings of the assessment tools, confirming that developing countries should develop their own systems. For the Myanmar case studies, to ensure sustainability, it is important to set related guidelines and ordinances from a long-term perspective followed by sustainable practices and lifestyles. The results of this study can be used to guide the sustainability pathways of developing countries and the diffusion of rating systems to these countries.

\section{REFERENCES}

[1] Cobbinah, P.B., Erdiaw-Kwasie, M.O. \& Amoateng, P., Rethinking sustainable development within the framework of poverty and urbanisation in developing countries. Environmental Development, 13, pp. 18-32, 2015. https://doi.org/10.1016/j.envdev.2014.11.001

[2] BRE. BREEAM Communities Technical Manual. SD 202- 0.1: 2012, BRE Global 2012.

[3] IBEC. CASBEE for Urban Development. Technical Manual 2014 edition. Institute for Building Environment and Energy Conservation, Japan, 2014.

[4] USGBC. LEED 2009 for Neighborhood Development. Congress for the New Urbanism, Natural Resources Defense Council, and the U.S. Green Building Council, US. 2014.

[5] Sharifi, A. \& Murayama, A., A critical review of seven selected neighborhood sustainability assessment tools. Environmental Impact Assessment Review, 38, pp. 73-87, 2013. https://doi.org/10.1016/j.eiar.2012.06.006

[6] Haughton, G. \& Hunter, C., Sustainable Cities, London; New York: Routledge, 2003.

[7] Maclaren, V.W., Urban sustainability reporting. Journal of the American Planning Association, 62(2), pp. 184-202, 1996. https://doi.org/10.1080/01944369608975684

[8] Shwe, T., Homma, R., Iki, K. \& Ito, J., Sustainability assessment of university campus through various rating systems. Proceeding 100th International Conference on Science, Technology, Engineering and Management, Nagoya, Japan, 7th January, 2017.

[9] http://www.glredcl.com/

[10] http://www.newstarlight.com.mm/

[11] http://digayeyarwaddy.com/ 